\title{
Energetic potential of Eucalyptus sp. wood cultivated in the Plaster's Pole of Araripe, PE, Brazil
}

\author{
Tarcila Rosa da Silva Lins ${ }^{1 *} \oplus$, Rafael Leite Braz $^{2} \oplus$, Thiago Cardoso Silva ${ }^{1} \oplus$,

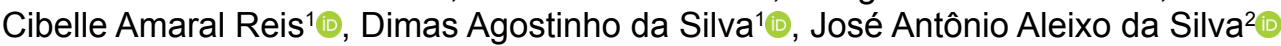

\footnotetext{
1 Universidade Federal do Paraná, Curitiba, PR, Brasil. E-mail: tarcila.lins@hotmail.com; thiagocardoso.pe@gmail.com; cibelleamaralreis@hotmail.com; dimas.agostinho.silva@gmail.com

2 Universidade Federal Rural de Pernambuco, Recife, PE, Brasil. E-mail: rlbraz.ufrpe@gmail.com; jaaleixo@uol.com.br
}

ABSTRACT: This study aimed to characterize the wood energetically and evaluate the quality of the charcoal produced from different Eucalyptus sp. clones, identifying the most suitable. The basic density of wood and was determined, then, the proximate chemical analysis and the calorific value were determined from charcoal. The annual energy production was estimated by the relationship between the wood production of these Eucalyptus clones and the information obtained in the previous steps. The experiment was conducted following a completely randomized design. The data were submitted to the homogeneity test of Cochran's variances when they presented significant differences, the means were compared by Tukey $(p=5 \%)$. The properties of wood and charcoal were correlated by Pearson's correlation analysis $(p=0.05)$. According to the results, the genetic material didn't influence the chemical composition of charcoal, however, the clones of the $E$. urophylla $\times E$. terticornis hybrids - C101 and E. urophylla - C39 showed better results concerning the basic density of the wood. In addition, the C101 hybrid showed the greatest wood production, as well as the mass of charcoal to be produced. Due to these characteristics, this hybrid presented a greater potential for annual energy production.

Key words: biomass; brazilian semiarid; charcoal; energy matrix

\section{Potencial energético de madeira de Eucalyptus sp. cultivado no Polo Gesseiro do Araripe, PE, Brasil}

RESUMO: Este estudo teve como objetivo caracterizar energeticamente a madeira e avaliar a qualidade do carvão produzido de diferentes clones de Eucalyptus sp., identificando o mais adequado. A densidade básica da madeira foi determinada, em seguida, a análise da química imediata e o poder calorífico foram identificados do carvão vegetal. A produção anual de energia foi estimada pela relação entre a produção de madeira desses clones de Eucalyptus e as informações obtidas nas etapas anteriormente citadas. 0 experimento foi conduzido seguindo um delineamento inteiramente casualizado. Os dados foram submetidos ao teste de homogeneidade de variâncias de Cochran's, quando eles apresentavam diferença significativa, as médias foram comparadas pelo teste de Tukey $(p=5 \%)$. As propriedades da madeira e do carvão vegetal foram correlacionadas pela análise de correlação de Pearson $(p=0,05)$. De acordo com os resultados, 0 material genético não influenciou a química imediata do carvão vegetal, entretanto, os clones de $E$. urophylla $\times$ E. terticornis híbrido - C101 e $E$. urophylla - C39, apresentaram melhores resultados considerando a densidade básica da madeira. Além disso, o híbrido C101 apresentou o maior potencial de produção de massa de madeira, bem como a massa de carvão a ser produzida. Devido a essas características, esse híbrido apresentou maior potencial de produção anual de energia.

Palavras-chave: biomassa; semiárido brasileiro; carvão vegetal; matriz energética

\footnotetext{
*Tarcila Rosa da Silva Lins - E-mail: tarcila.lins@hotmail.com (Corresponding author)

Associate Editor: Rafael Rodolfo de Melo
} 


\section{Introduction}

Historically, forest biomass has had an important role in the energy matrix and has been widely used as a renewable source of energy. Thus, it has stirred interest to improve the quality of the carbonization system to increase the efficiency of the process when applied at its secondary source in the steel sector or even in domestic use (Trugilho et al., 2015). According to the National Energy Balance (EPE, 2019), biomass is a renewable resource in the Brazilian energy matrix, constituting about $8.5 \%$ of the energy generated, second only to hydraulic energy and natural gas, which are non-renewable resources and contribute 66.6 and $8.6 \%$, respectively.

For energy demand, some Brazilian regions need forest biomass to complement the raw material required to generate energy. Such problem occurs in the Araripe region of, within the semiarid of Pernambuco, where the Plaster's Pole of Araripe is located. Regarding the exploitation of gypsum, a mineral that turns into plaster after dehydration, the region comprises 22 mines, with 153 gypsum calciners operating on forest biomass, and 420 plasterboard industries, consuming $54.390 \mathrm{~m}^{3}$ of firewood per month (Gadelha et al., 2018).

In this context, it is necessary to expand the variety of raw materials used for energy production in this region, since a large part of the biomass used by these industries exploits the Caatinga; the dominant semiarid vegetation. One alternative is the implantation of plantations of fast-growing species that are specifically destined for energy use, since they are renewable sources, seeking affordable production costs for the calcining industries and rural producers in the semiarid region. However, it is necessary to better understand the characteristics of the biomass that will be used for this purpose.

The characteristics that directly influence the quality of wood and charcoal (a secondary product) are basic density, high percentages of charcoal yield, high fixed carbon content and a low percentage of volatile matter and mineral residues (Reis et al., 2012). These properties are related to calorific value and, consequently, energy efficiency. Other physical, chemical, mechanical, and anatomical properties must also be considered and are correlated to the energy characteristics of the raw material. This desirable set of properties is found in several exotic species of the genus Eucalyptus that are widely used for energy purposes and well adapted to Brazilian edaphoclimatic conditions, allowing them to develop rapidly (Trugilho et al., 2015).

Therefore, it is necessary to understand the properties of wood and charcoal and their variations, as well as to relate them to the characteristics of the plantation from which the material originates. Thus, the aim of this work was to energetically characterize the wood and to evaluate the quality of the charcoal produced from different Eucalyptus sp. clones grown in the Pernambuco semiarid region, as well as identify which clone(s) are best for energy production according to their wood and charcoal properties and field characteristics.

\section{Materials and Methods}

\section{Study area and sampling}

Samples of six Eucalyptus sp. genetic materials were used (Table 1), from a plantation at the Experimental Station of the Instituto Agronômico Pernambuco (IPA) located in Chapada do Araripe, Araripina municipality (0729'00' S; 4036'00' W), semiarid region of Pernambuco state, in Brazil. The locality has red-yellow latosol soil and the climate is hot and dry with summer rains, classified as $\mathrm{DdB}^{\prime} 4 \mathrm{a}^{\prime}$ according to Köppen (Silva et al., 2016, 2017).

The plantation was installed in March 2002, with a spacing of $3.0 \times 2.0 \mathrm{~m}$, and the first harvest was carried out in 2009 when trees were 7.5 years old. The wood used in this study came from the second growth and was 5.5 years old, which was collected in June 2015. According to Gadelha et al. (2018), the second growth obtained the Average Annual Increment (AAI) values well below those of the first growth due to a severe drought that occurred in 2012 and 2013. However, such AAI values were still higher than those for Caatinga vegetation.

After cutting the trees, disks were removed at the positions of 0,50 and $100 \%$ of the commercial height of the bole, considering a minimum diameter of $5.0 \mathrm{~cm}$. Five trees were sampled for each treatment. The wood density was obtained for each disc, while for proximate analysis and the calorific value of wood and charcoal composite samples consisted of the homogenization of the chip discs.

\section{Determination of basic wood density}

The procedure used to analyze the basic wood density was the NBR 11941 standard (ABNT, 2003).

Table 1. Description of the Eucalyptus sp. genetic materials with their respective clone identifications and the average annual increment (AAI) from an experiment developed at the Experimental Station of the Instituto Agronômico de Pernambuco (IPA), in Araripina, $\mathrm{PE}$, Brazil.

\begin{tabular}{clcc}
\hline Treatment & \multicolumn{1}{c}{ Genetic materials } & Code & $\begin{array}{c}\text { AAI } \\
\left(\mathbf{m}^{\mathbf{3}} \text { ha }^{-1} \text { year }^{-1}\right)\end{array}$ \\
\hline T1 & Hybrid of E. urophylla $\times$ E. tereticornis of Laura (controlled pollination) & C80 & 9.17 \\
T2 & Hybrid of E. urophylla $\times$ E. tereticornis of Laura (controlled pollination) & C101 & 12.65 \\
T3 & Hybrid of E. urophylla (natural crossing) & C39 & 13.65 \\
T4 & Hybrid of E. urophylla $\times$ E. tereticornis of Laura (controlled pollination) & C158 & 10.04 \\
T5 & Hybrid of E. urophylla (natural crossing) & C41 & 10.30 \\
T6 & Hybrid of $E$. urophylla (natural crossing) & C33 & 5.18 \\
\hline
\end{tabular}




\section{Carbonization}

After determining the basic density, the discs were reduced to chips to obtain composite samples for each treatment. From this, five repetitions were obtained for carbonization and proximate analysis of the resulting charcoal.

The carbonization process took place in a Mufla type reactor, with adaptation, for 210 minutes. For this, $100 \mathrm{~g}$ of wood chips were used per repetition, in which the material remained at a temperature of $150 \stackrel{\circ}{ } \mathrm{C}$ during the first $30 \mathrm{~min}$, subsequently it was raised to 250 o C for another $30 \mathrm{~min}$. After this period, a heating rate of $1.4 \stackrel{\circ}{ } \mathrm{C} \mathrm{min}^{-1}$ was applied, which was maintained until reaching $460 \pm 10 \stackrel{\circ}{ }$, which ended with the carbonization process (Vale et al., 1996).

\section{Proximate chemical analysis of charcoal}

After the carbonization process, the gravimetric yield (\%) in charcoal was determined by dividing the dry charcoal mass by the dry wood mass. The proximate chemical of charcoal was carried out by analyzing the D1762-84 standard (ASTM, 2013a) to determine the contents of volatile matter, ash, and fixed carbon on a dry basis. The yield of fixed carbon was obtained by the product of the gravimetric yield of carbonization and the fixed carbon content of charcoal.

\section{Determination of calorific value}

The high calorific value (HCV) of the wood was obtained in a calorimeter (IKA ${ }^{\circledR}$ WERKE C5003 model) following the D5865 standard (ASTM, 2013b). The calorimeter was calibrated based on heating of benzoic acid PA, resulting in 2,959 \pm 30.4 cal ${ }^{\circ} \mathrm{C}^{-1}$ (CV $\left.=1.03 \%\right)$. This value was used to determine the $\mathrm{HCV}$, according to Equation 1. The analyzes were performed in duplicate. For charcoal production, the HCV was estimated from Equation 2, defined by Vale et al. (2002).

$$
\mathrm{SCV}=\frac{\mathrm{C} \cdot \Delta \mathrm{T}}{\mathrm{m}}
$$

where:

$$
\begin{aligned}
& \mathrm{HCV} \text { - high calorific value, cal g}{ }^{-1} ; \\
& \mathrm{C} \quad-2,959 \pm 30.4 \mathrm{cal}^{\circ} \mathrm{C}^{-1} ; \\
& \Delta \mathrm{T} \quad \text { - temperature variation, }{ }^{\circ} \mathrm{C} \text {; and, } \\
& \mathrm{m} \quad \text { - wood mass, } \mathrm{g} .
\end{aligned}
$$$$
\text { HCVcharcoal }=4,934.43+33.27 \cdot \% \mathrm{FC}
$$

where:

HCVcharcoal - charcoal's high calorific value, cal g-1; and, \%FC - fixed carbon content in charcoal, \%.

For each species, the lower calorific value (LCV) of wood and charcoal were estimated as proposed by Brand (2010), as shown in Equation 3. For this calculation, the average values of hydrogen used for Eucalyptus sp. were defined according to the literature, which are: $3.34 \%$ for charcoal (Oliveira et al., 1982; Assis et al., 2012; Protásio et al., 2013; Soares et al., 2014), and $6.0 \%$ for wood (Brand, 2010).

$$
\mathrm{LCV}=\mathrm{HCV}-600 \cdot(0.09 \cdot \mathrm{H})
$$

where:

LCV - lower calorific value, cal g ${ }^{-1}$;

$\mathrm{HCV}$ - high calorific value, cal g-1; and,

$\mathrm{H} \quad$ - hydrogen, \%.

\section{Estimated annual energy production}

This step was carried out to determine the potential energy production of charcoals from different Eucalyptus sp. genetic materials. For this, the dry mass of wood was obtained ( $\mathrm{kg} \mathrm{ha}^{-1}$ year ${ }^{-1}$ ) based on basic wood density $\left(\mathrm{kg} \mathrm{m}^{-3}\right)$ and the average annual increment $\left(\mathrm{m}^{3} \mathrm{ha}^{-1}\right)$. The annual amount of charcoal $\left(\mathrm{kg} \mathrm{ha}^{-1}\right)$ produced from this wood was estimated by relating the dry mass of wood to its gravimetric yield in charcoal. The carbon mass was estimated ( $\mathrm{kg} \mathrm{ha}^{-1}$ year $^{-1}$ ) by relating the mass of charcoal and the fixed carbon content in charcoal. Finally, the amount of energy that would be produced annually (kcal year $^{-1}$ ) with this charcoal was obtained from the relationship between the charcoal mass and the high calorific value of the charcoal (kcal kg-1).

Then, the amounts of electricity produced annually by each clone were estimated, based on the basic relationship in which $1 \mathrm{kcal}=0.00116 \mathrm{kwh}$ (Santos et al, 2013). Finally, to calculate the theoretical potential of conversion to electrical energy, the average efficiency was $20 \%$ (Nogueira \& Lora, 2003).

\section{Statistical analysis}

The design used was entirely random. The data obtained was subjected to the Cochran's homogeneity test and compared using analysis of variance (ANOVA). For samples that showed a statistical difference between the treatments according to the $\mathrm{F}$ test, the means were compared for the analyzed variables using the Tukey test at $5 \%$ probability. Finally, a Pearson correlation analysis was performed between the properties of wood and charcoal, with a significance level of $p=0.05$. All analyzes were performed using RStudio software version 3.6.3.

\section{Results}

\section{Basic density of wood}

The average for basic wood densities ranged from 0.53 to $0.64 \mathrm{~g} \mathrm{~cm}^{-3}$ (Figure 1) and are classified as medium density wood. The treatments T1 and T2, which correspond to clones C101 and C41, respectively, presented the highest values for this variable.

\section{Proximate chemical analysis of charcoal}

According to the ANOVA, statistical differences were only observed between treatments for ash contents (Table 2), whose differentiation of the means for this variable is shown in Table 3. As the other variables did not show statistical difference, the correspondent letters referring to the Tukey 


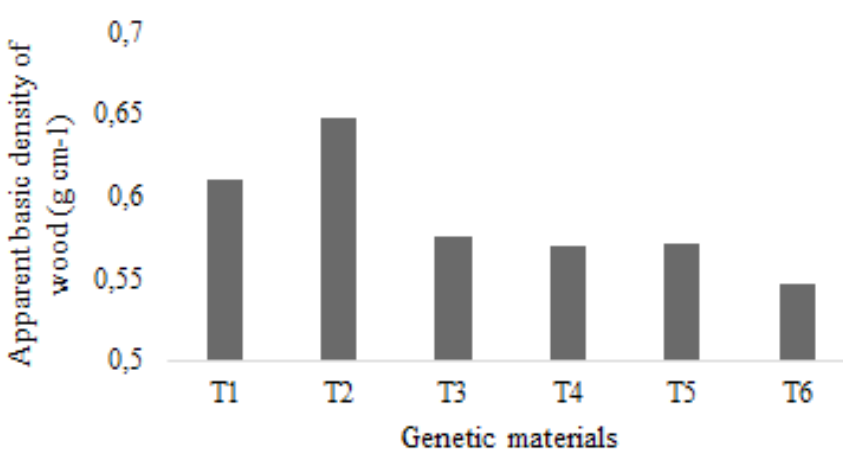

Figure 1. Average values of basic density of Eucalyptus $s p$. with 5.5 years from planting at the Experimental Station of the Instituto Agronômico Pernambuco (IPA), in Araripina, PE, Brazil.

test for them were not added in the table. The data showed homogeneous variances.

\section{Calorific value of wood and charcoal}

The values obtained from the LCV can be found in Figure 2, varying between 4,109 and $4,303 \mathrm{kcal} \mathrm{kg}^{-1}$ for wood, with the highest value corresponding to $\mathrm{T} 1$, and varying between 6,351 and $6,890 \mathrm{kcal} \mathrm{kg}^{-1}$ for charcoal.

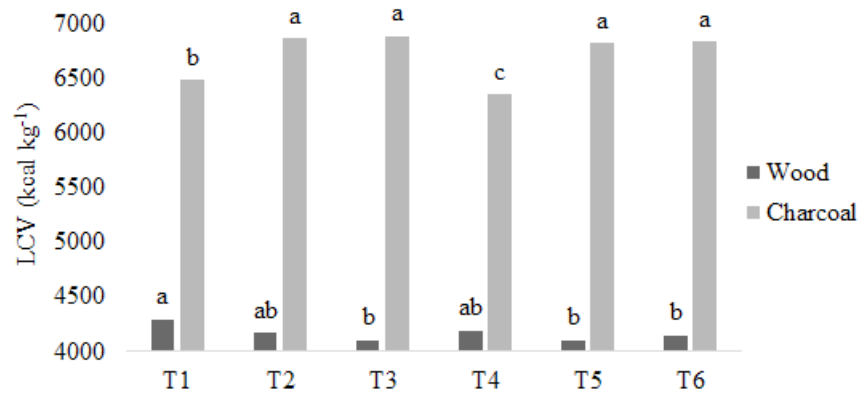

Figure 2. Lower calorific value (LCV) of wood (coefficient of variation $=0.89 \%$ ) and charcoal (coefficient of variation $=0.66$ $\%)$ of Eucalyptus sp. clones with 5.5 years of planting at the Experimental Station of the Instituto Agronômico Pernambuco (IPA), in Araripina, PE, Brazil.

\section{Estimated annual energy production}

According to the results presented in Table 4, clone T2 presents the highest estimate of annual energy production, and T6 presents the lowest production.

\section{Correlation analysis}

From the correlation analysis in Figure 3, only the ash content correlates to the basic density of Eucalyptus sp.

Table 2. Analysis of variance of the proximate analysis of charcoal from Eucalyptus sp. genetic materials originating from an experimental plantation in Araripina, PE, Brazil.

\begin{tabular}{|c|c|c|c|c|c|c|c|c|c|c|}
\hline \multirow{2}{*}{$\begin{array}{c}\text { Variation } \\
\text { source }\end{array}$} & \multirow[b]{2}{*}{ GL } & \multicolumn{6}{|c|}{ "F" values } & \multirow{2}{*}{$\begin{array}{l}\text { Variation } \\
\text { source }\end{array}$} & \multirow[b]{2}{*}{ GL } & \multirow{2}{*}{$\begin{array}{c}\text { "F" value } \\
\text { LCV } \\
\text { wood }\end{array}$} \\
\hline & & \%Ash & \%VM & $\% G Y$ & $\% F C$ & \%FCY & $\begin{array}{c}\text { LCV } \\
\text { charcoal }\end{array}$ & & & \\
\hline $\begin{array}{l}\text { Treatments } \\
\text { Residue }\end{array}$ & $\begin{array}{c}5 \\
18\end{array}$ & $66.62^{*}$ & $0.65^{\text {ns }}$ & $1.75^{\mathrm{ns}}$ & $0.44^{\text {ns }}$ & $0.93^{\text {ns }}$ & $108.35^{*}$ & $\begin{array}{l}\text { Treatments } \\
\text { Residue }\end{array}$ & $\begin{array}{l}5 \\
6\end{array}$ & $7.47^{*}$ \\
\hline Total & 23 & & & & & & & Total & 11 & \\
\hline
\end{tabular}

Where: ns - not significant at $5 \%$ probability; ${ }^{*}$ - significant at $5 \%$ probability; $\mathrm{GL}=$ degrees of freedom; VM = volatile matter; GY = gravimetric yield; FC = fixed carbon; FCY = fixed carbon yield; $L C V=$ lower calorific value.

Table 3. Average results for the contents of Ash (\%Ash), volatile matter (\%VM), gravimetric yield (\%GY), fixed carbon (\%FC), and fixed carbon yield (\%FCY) from charcoal treatments that originated from Eucalyptus sp. genetic materials from an experimental plantation in Araripina, PE, Brazil.

\begin{tabular}{cccccc}
\hline Treatments & \%Ash & \%VM & \%FC & \%GY & \%FCY \\
\hline T1 & $0.96 \mathrm{~b}$ & 38.88 & 62.08 & 33.70 & 20.55 \\
T2 & $1.32 \mathrm{a}$ & 38.50 & 62.2 & 33.19 & 21.10 \\
T3 & $0.39 \mathrm{~cd}$ & 37.93 & 62.46 & 33.02 & 22.49 \\
T4 & $0.52 \mathrm{~cd}$ & 38.26 & 62.26 & 32.83 & 20.51 \\
T5 & $0.59 \mathrm{c}$ & 38.45 & 62.14 & 33.33 & 21.32 \\
T6 & $0.35 \mathrm{~d}$ & 38.12 & 62.22 & 32.62 & 20.46 \\
Mean & 0.69 & 38.36 & 62.33 & 33.11 & 21.07 \\
CV (\%) & 13.58 & 2.14 & 1.31 & 1.75 & 7.7 \\
\hline
\end{tabular}

Means followed by the same letter do not differ statistically from each other according to the Tukey test at a $5 \%$ probability level.

Table 4. Estimated annual production of energy produced from charcoal originating from different Eucalyptus sp. genetic material from an experimental plantation in Araripina, PE, Brazil.

\begin{tabular}{|c|c|c|c|c|c|c|}
\hline \multirow{2}{*}{ Treatments } & \multirow{2}{*}{$\begin{array}{l}\text { Dry wood mass } \\
\left(\mathrm{kg} \mathrm{ha}^{-1} \text { year }^{-1}\right)\end{array}$} & \multirow{2}{*}{$\begin{array}{l}\text { Volume of wood } \\
\left(\mathrm{m}^{3} \mathrm{ha}^{-1} \text { year }^{-1}\right)\end{array}$} & \multirow{2}{*}{$\begin{array}{l}\text { Charcoal mass } \\
\left(\mathrm{kg} \mathrm{ha}^{-1} \text { year-1) }^{-1}\right)\end{array}$} & \multirow{2}{*}{$\begin{array}{l}\text { Carbon mass } \\
\left(\mathrm{kg} \mathrm{ha}^{-1} \text { year }^{-1}\right)\end{array}$} & \multicolumn{2}{|c|}{ Potential energy } \\
\hline & & & & & $\left(\right.$ (kcal ha $^{-1}$ year-1) $^{-1}$ & $\left(k w h h^{-1}\right.$ year $\left.^{-1}\right)$ \\
\hline T1 & 5,590 & 9.56 & 1,890 & 980 & 2,510 & $2,921.36$ \\
\hline $\mathrm{T} 2$ & 8,180 & 12.78 & 2,720 & 1,720 & 3,840 & $4,457.54$ \\
\hline T3 & 7,490 & 12.91 & 2,440 & 1,540 & 3,440 & $3,995.78$ \\
\hline T4 & 5,720 & 10.79 & 1,880 & 900 & 2,450 & $2,852.50$ \\
\hline T5 & 5,880 & 9.19 & 2,010 & 1,250 & 2,810 & $3,269.60$ \\
\hline T6 & 2,830 & 5.15 & 920 & 580 & 1,360 & $1,505.68$ \\
\hline
\end{tabular}




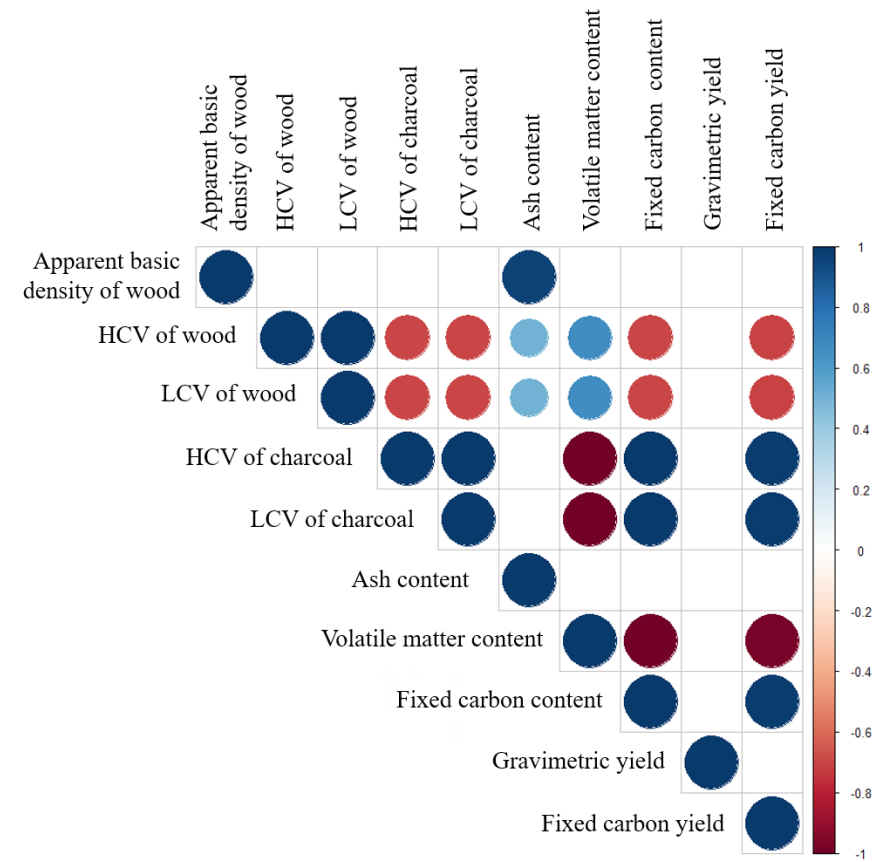

Figure 3. Correlation analysis between the variables: basic wood density; High calorific value (HCV) and lower calorific value (LCV) of wood; high calorific value (HCV) and lower calorific value (LCV) of charcoal; Ashes; volatile matter; fixed carbon; gravimetric yield and fixed carbon yield.

wood, with no interaction between the calorific value of the wood and others charcoal characteristics. Additionally, the ash content was not influenced by any other charcoal characteristics. The characteristics in white in Figure 3 no presented correlation.

\section{Discussion}

\section{Basic density of wood}

In general, the wood of the genus Eucalyptus used to produce charcoal has a basic density of $\sim 0.54 \mathrm{~g} \mathrm{~cm}^{-3}$, which is considered a medium density (Silveira et al., 2013; Carneiro et al., 2014). Thus, the values obtained in this study corroborate using this wood for the charcoal production. However, the values are still below what is normally found in Caatinga species, which are denser than Eucalyptus species and, in turn, have longer combustion and greater potential for energy production (Protásio et al., 2013). On the other hand, they have higher average annual increments and shorter rotations, which directly contributes to mitigate the effects of deforestation of Caatinga vegetation by offering more wood in less time (Silva et al., 2016, 2017).

Studying this variable is particularly important for determining the quality of charcoal. According to Vale et al. (2010), the basic density is linked to the production of charcoal and its quality, being one of the properties that most influences in the final product.

The apparent basic density of wood is an important characteristic that directly influences the planning of wood energy use, especially when considering the dimensions of biomass for transportation (Brand, 2010). Since the clones used herein were all classified as medium density, they would have a substantial mass/volume ratio, which could cause difficulties for transportation. Brand (2010) also states that the density influences the dimensions of the wood parts that are used in the furnaces, as well as the dimensions of the power generation unit, depending on the yield and energetic efficiency of the biomass.

\section{Proximate chemical analysis of charcoal}

Regarding the percentage of ash, most of the results fall within the expected range, since they varied from 0.35 to $1.32 \%$. The values obtained were close to those found by Reis et al. (2012), who found between $0.44 \%$ and $0.81 \%$ in a study carried out with $E$. urophylla clones. However, the T2 treatment showed the highest percentage among the six clones (1.32\%). This clone differed statistically from the others, as well as T1. The lowest values were observed in T3, $\mathrm{T} 4$, and T6. The variations in ash contents may have occurred due to the location influencing the mineral composition of each tree or the presence of impurities from the field during cutting, harvesting, transport, or storage phases.

Therefore, low quantities of these elements are desirable since these minerals do not participate in the combustion process. Besides, a high ash content may indicate contamination by soil residues, cause the furnace in which it is being burned to deteriorate, and, if used for steelmaking, impair the quality of pig iron (Santos et al, 2016).

The values referring to the fixed carbon yield varied between 20.46 and $22.49 \%$ and did not present significant differences between the clones' means. These values are lower than charcoal from Eucalyptus $s p$. found in the literature, i.e., close to $25 \%$ (Protásio et al., 2013).

The relationship between volatile compounds and carbon fixed in charcoal is inversely proportional. The values for volatile matter (35.42 to $37.97 \%$ ) were higher than those found in the literature (Reis et al., 2012; Soares et al., 2014; Santos et al., 2016) consequently, the levels for fixed carbon (62.08 to 62.82\%) were below expectations.

Regarding the contents of volatile matter and fixed carbon, the opposite is desired, that is, the content of volatile matter should be lower and that of fixed carbon should be higher. These characteristics would provide a slower burning charcoal, improving its quality (Brand, 2010; Reis et al., 2012).

The variable yield of fixed carbon covers characteristics of charcoal productivity and quality, so the higher the yield, the more favorable the properties for energy purposes (Soares et al., 2014). Therefore, if higher yields of fixed carbon were obtained, the quality of charcoal produced from the materials used herein would also be higher.

Regarding the gravimetric yield, there was a conversion of firewood to charcoal in a proportion of 3 to 1 . Thus, the results were satisfactory, since the higher the gravimetric yield, the more wood will be transformed into coal in the process, thus having a better use of raw material. 


\section{Calorific value and estimated annual energy production}

The results found for the high calorific value (HCV) of the wood varied between 4,426 and 4,594 $\mathrm{kcal} \mathrm{kg}^{-1}$ and are close to those found by Juizo et al. (2017) for clones of Eucalyptus, corresponding to values between $4,468.33$ and $4,753.33 \mathrm{kcal}$ $\mathrm{kg}^{-1}$. Since this value considers the heat obtained by recovering hydrogen in combustion, the energy characteristics from the value of the lower calorific value (LCV) were observed as expressing the effective value available for burning in the combustible material.

These values may have been influenced by the carbonization methods adopted herein, considering the final temperature and exposure time at the end of the process. According to Silva et al. (2018), charcoal quality is determined by the final combustion temperature and the speed of heating to convert wood into charcoal. The lowest values for the LCV were obtained by clones T1 and T4, with the others showing no significant difference. For wood, the clones showed a certain homogeneity of this characteristic since their values varied only slightly.

According by Brand (2010), the average calorific value of woody materials in natura with $25 \%$ humidity is close to 3,300 $\mathrm{kcal} \mathrm{kg}^{-1}$, as well as the average HCV and LCV values of charcoal are 6,800 and 6,500 $\mathrm{kcal} \mathrm{kg}^{-1}$, respectively. Therefore, the LCVs found in this work are considered satisfactory to produce energy from this raw material, corroborating the use of these clones for this purpose.

It is observed that eucalyptus plantations in the semi-arid regions can present wood production above $10 \mathrm{~m}^{3} \mathrm{ha}^{-1}$ year $\mathrm{r}^{-1}$. And, from this production, they are able of generating about 2.5 tons of charcoal per year.

It is estimated that the annual consumption of firewood to supply plaster production at the Araripe Pole is 652,680 $\mathrm{m}^{3}$ (Gadelha et al., 2018). Regarding the best genetic material from the annual energy production of charcoal produced by these Eucalyptus sp. clones, the T2 clone had the best results, according to the annual production of wood. Therefore, extrapolating the values, considering only the volume of wood and not the amount of energy produced, it would take about 50,550 hectares of plantations for this clone to supply the annual energy demand of the industries located in that region.

Depending on the genetic material grown, there may be a greater fixation of carbon mass in this wood, and among the clones studied, clone T2 also stood out for its high volumetric production, being the second one with the highest production among the six clones. This way, in addition to presenting great energy potential, its planting can contribute to alleviate some environmental problems resulting from climate change, through the accumulation of carbon in the standing biomass.

\section{Correlation analysis}

The correlation between wood density and the other important properties for charcoal production is always mentioned in articles with this theme. However, the authors are not always able to support the existence of this correlation. Considering the charcoal yield variable along with the basic density, Vital et al. (1986) found negative results regarding this correlation. On the other hand, Reis et al. (2012) found a positive correlation between charcoal yield and density in studies with E. urophylla. In this work, the density showed a positive correlation only with the ash content, which often showed values above those found in the literature. Therefore, this high content of inorganics can influence the weight of biomass as a function of volume.

The calorific value is a variable that is influenced by the percentage of fixed carbon and mineral residues, which can contribute or hinder its performance. The LCV is positively influenced by the percentage of fixed carbon since the higher this content, the more carbon there is available for burning and the longer the material will last. On the other hand, volatile matter and ash content are inversely proportional to the calorific value since the former are released during burning and the ash does not contribute to combustion, which is considered waste at the end of the process (Carneiro et al., 2014).

The calorific value of charcoal showed a significant negative correlation with the content of volatile matter, as well as a positive one with the content of fixed carbon and its yield in fixed carbon. As previously discussed, the amount of fixed carbon and volatile matter have an inversely proportional relationship and a higher amount of carbon in charcoal is an indication of a better burning quality for a material.

\section{Conclusion}

The clones of the hybrid E. urophylla $\times$ E. terticornis of Laura (controlled pollination) - C101 and the hybrid E. urophylla (natural cross) - C39 showed better results concerning the basic wood density.

As for the proximate chemical of charcoal, the genetic material only influenced the content of inorganic elements. In this way, among the material evaluated herein, these two clones are most indicated for charcoal production in the semiarid of Pernambuco.

These results contribute to the choice of raw materials with aptitude for energy production, and which present productive potential in semiarid regions. Therefore, the values found in the present study indicate that using Eucalyptus sp. is feasible for energy purposes and can be used to supply the demands of regions with high consumption of firewood and charcoal, and as an alternative to avoid cutting native vegetation.

\section{Acknowledgments}

We thank the Conselho Nacional de Desenvolvimento Científico e Tecnológico (CNPq) and the Coordenação de Aperfeiçoamento de Pessoal de Nível Superior Brasil (CAPES) - Finance Code 001 for partially financing this study. We thank the Fundo Nacional de Desenvolvimento da Educação (FNDE), for providing the scholarships to the students linked to PET AgroEnergia who conducted this research. Finally, we thank Professor Dimas Agostinho da Silva for making the structure of the Forest Biomass and Bioenergy Energy Laboratory (UFPR) available for carrying out part of the analyzes. 


\section{Compliance with Ethical Standards}

Funding: Conselho Nacional de Desenvolvimento Científico e Tecnológico (CNPq), Coordenação de Aperfeiçoamento de Pessoal de Nível Superior - Brasil (CAPES) - Finance Code 001 and Fundo Nacional de Desenvolvimento da Educação (FNDE).

Conflict of interest: Authors declare that there are no conflicts of interest (professional or financial) that may influence the article.

Author contribution: TRSL, CAR, TCS, RLB; Data curation: TRSL, CAR, TCS; Formal analysis: TRSL, TCS; Investigation: TRSL, CAR, TCS; Methodology: TRSL, TCS, RLB; Project administration: TRSL, CAR, TCS; Resources: RLB, JAAS, DAS; Supervision: RLB; Validation: TRSL, CAR, TCS; Visualization: TRSL, TCS; Writing - original draft: TRSL, TCS; Writing - review \& editing: TRSL, CAR, TCS, RLB, JAAS, DAS.

\section{Literature Cited}

American Society for Testing and Material - ASTM. D1762-84 2013: Standard test method for chemical analysis of wood charcoal. West Conshohocken: ASTM, 2013a. 2p.

American Society for Testing and Material - ASTM. D5868 2013: Standard test method for gross calorifc value of coal and coke. West Conshohocken: ASTM, 2013b. 2p.

Assis, M.R.; Protásio, T. P.; Assis, C.O.; Trugilho, P.F.; Santana, W.M.S. Qualidade e rendimento do carvão vegetal de um clone híbrido de Eucalyptus grandis x Eucalyptus urophylla. Pesquisa Florestal Brasileira, v.32, n.71, p.291-302, 2012. https://doi. org/10.4336/2012.pfb.32.71.291.

Associação Brasileira de Normas Técnicas - ABNT. NBR 11941: madeira - determinação da densidade básica. Rio de Janeiro: ABNT, 2003. 6p.

Brand, M.A. Energia de biomassa florestal. Rio de Janeiro: Interciência, 2010. 114p.

Carneiro, A.C.O. Potencial energético da madeira de Eucalyptus sp. em função da idade e de diferentes materiais genéticos. Revista Árvore, v.38, n.2, p.375-381, 2014. https://doi.org/10.1590/ S0100-67622014000200019.

Empresa de Pesquisas Energéticas - EPE. Balanço energético nacional 2019: ano base 2019. Rio de Janeiro: Ministério de Minas e Energia, 2019. 67p. (EPE. Relatório Final). https://www. epe.gov.br/sites-pt/publicacoes-dados-abertos/publicacoes/ PublicacoesArquivos/publicacao-377/topico-494/BEN\%20 2019\%20Completo\%20WEB.pdf. 22 Jun. 2020.

Gadelha, F.H.L; Silva, J.A.A.; Ferreira, R.L.C. Viabilidade econômica do cultivo de clones de Eucalyptus spp. em função do espaçamento e do sistema silvicultural, em Araripina-PE. Anais da Academia Pernambucana de Ciência Agronômica, v.15, n.2, p.105-123, 2018. http://www.journals.ufrpe.br/index.php/apca/article/ view/2148. 24 Jun. 2020.

Juizo, C.G.F.; Lima, M.R.; Silva, D.A. Qualidade da casca e da madeira de nove espécies de Eucalipto para a produção de carvão vegetal. Revista Brasileira de Ciências Agrárias, v.12, n.3, p.386-390, 2017. https://doi.org/10.5039/agraria.v12i3a5461.
Nogueira, L.A.H.; Lora, E.E.S. Dendroenergia: fundamentos e aplicações. 2.ed. Rio de Janeiro: Interciência, 2003. 199p.

Oliveira, J.B.; Gomes, P.A.; Almeida, M.R. Propriedades do carvão vegetal. In: Fundação Centro Tecnológico de Minas Gerais CETEC (Ed.). Carvão vegetal: destilação, propriedades e controle de qualidade. Belo Horizonte: CETEC, 1982. p. 39-60. (CETEC. Série de Publicações Técnicas, 6).

Protásio, T.P.; Couto, A.M.; Reis, A.A.; Trugilho, P.F.; Godinho, T.P. Potencial siderúrgico e energético do carvão vegetal de clones de Eucalyptus spp. aos 42 meses de idade. Pesquisa Florestal Brasileira, v.33, n.94, p.136-149, 2013. https://doi. org/10.4336/2013.pfb.33.74.448.

Reis, A.A.; Protásio, T.P.; Melo, I.C.N.A.; Trugilho, P.F.; Carneiro, A.C.C. Composição da madeira e do carvão vegetal de Eucalyptus urophylla em diferentes locais de plantio. Pesquisa Florestal Brasileira, v.32, n.71, p.277-290, 2012. https://doi. org/10.4336/2012.pfb.32.71.277.

Santos, R.C.; Carneiro, A.C.O.; Pimenta, A.S.; Castro, R.V.O.; Marinho, I.V.; Trugilho, P.F.; Alves, I.C.N.; Castro, A.F.N.M. Potencial energético da madeira de espécies oriundas de plano de manejo florestal no estado do Rio Grande do Norte. Ciência Florestal, v.23, n.2, p.491-502, 2013. http://dx.doi. org/10.5902/198050989293.

Santos, R.C.; Carneiro, A.C.O.; Vital, B.R.; Castro, R.V.O., Vidaurre, G.B.; Trugilho, P.F.; Castro, A.F.N.M. Influência das propriedades químicas e da relação siringil/guaiacil da madeira de eucalipto na produção de carvão vegetal. Ciência Florestal, v.26, n.2, p.657-669, 2016. https://doi.org/10.5902/1980509822765.

Silva, J.A.A.; Rocha, K.D.; Ferreira, R.L.C.; Tavares, J.A. Modelagem do crescimento volumétrico de clones de eucalipto (Eucalyptus urophylla) no Polo Gesseiro do Araripe-PE. Anais da Academia Pernambucana de Ciência Agronômica, v.13/14, p.173-190, 2016/2017. http://www.journals.ufrpe.br/index.php/apca/ article/view/1901. 19 Jun. 2020.

Silva, R.C.; Marchesan, R.; Fonseca, M.R.; Dias, A.C.C.; Viana, L.C. Influência da temperatura final de carbonização nas características do carvão vegetal de espécies tropicais. Pesquisa Florestal Brasileira, v.38, e201801573, 2018. https://doi. org/10.4336/2018.pfb.38e201801573.

Silveira, L.H.C.; Rezende, A.V.; Vale, A.T. Teor de umidade e densidade básica da madeira de nove espécies comerciais amazônicas. Acta Amazônica, v.43, n.2, p.179-184, 2013. https://doi.org/10.1590/S0044-59672013000200007.

Soares, V.C.; Bianchi, M.L.; Trugilho, P.F.; Pereira, A.J.; Höfler, J. Correlações entre as propriedades da madeira e do carvão vegetal de híbridos de eucalipto. Revista Árvore, v.38, n.3, p.543-549, 2014. https://doi.org/10.1590/s010067622014000300017

Trugilho, P.F.; Goulart, S.L.; Assis, C.O.; Couto, F.B.S.; Alves, I.C.N.; Protásio, T.P.; Napoli, A. Características de crescimento, composição química, física e estimativa de massa seca de madeira em clones e espécies de Eucalyptus jovens. Ciência Rural, v.45, n.4, p.661-666, 2015. https://doi.org/10.1590/0103$8478 \mathrm{cr} 20130625$. 
Vale, A.T., Abreu, V.L.S., Gonçalez, J.C., Costa, A.F. Estimativa do poder calorífico superior do carvão vegetal de madeiras de Eucalyptus grandis em função do teor de carbono fixo e do teor de materiais voláteis. Brasil Florestal, v.21, n.73, p.47-52, 2002. http://www.bdpa.cnptia.embrapa.br/consulta/busca?b=ad\& id $=305880$ \&biblioteca=vazio \&busca=autoria:\%22ABREU. $\% 20$ V.\%20L.\%20S.\%22\&qFacets=autoria:\%22ABREU.\%20V.\%20L.\%20 S.\%22\&sort=\&paginacao=t\&paginaAtual=1. 19 Jun. 2020.

Vale, AT; Dias, I.S.; Santana, M.A.E. Relações entre propriedades químicas, físicas e energéticas da madeira de cinco espécies de cerrado. Ciência Florestal, v.20, n.1, p.137-145, 2010. http:// dx.doi.org/10.5902/198050981767.
Vale, A.T.; Nogueira, M.V.P.; Silva, M.A. Rendimento da carbonização e qualidade do carvão vegetal de madeiras do cerrado em comparação ao Eucalyptus grandis. Revista Árvore, v. v.20, n.1, p.93-99, 1996. https://cutt.ly/9hDpAjH. 24 Jun. 2020.

Vital, B.R.; Jesus, R.M.; Valente, O.F. Efeito da constituição química e da densidade da madeira de clones de Eucalyptus grandis na produção de carvão vegetal. Revista Árvore, v.10, n.2, p.151-160, 1986. https://books.google.com.br/books?id=NOSaAAAAIAAJ\&p

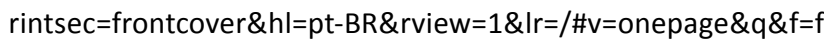
alse. 22 Jun. 2020. 